\title{
Bioclimatic zoning and trend analysis applied to broilers
}

[Zoneamento bioclimático e análise de tendência aplicados a frangos de corte]

\author{
P.T.L. Oliveira' ${ }^{1}$, A.L.N. Amaro $^{2}$, T. Yanagi Júnior ${ }^{2}$, G.A.S. Ferraz ${ }^{2}$, S.N.M. Yanagi ${ }^{2}$
}

${ }^{1}$ Instituto Federal de Educação Ciência e Tecnologia do Sertão Pernambucano - Petrolina, PE

${ }^{2}$ Universidade Federal de Lavras - Lavras, MG

\begin{abstract}
The objective of the present study was to establish the bioclimatic zoning by the temperature and humidity index (THI), considering a historical period and a future scenario, in order to represent the thermal environment for broiler breeding in the State of Minas Gerais. A historical series (1976 - 2014) of THI minimum, average and maximum calculated based on data from 48 conventional meteorological stations was used, belonging to the National Institute of Meteorology of the State of Minas Gerais. The analysis of the temporal series was based on the Mann-Kendall test and linear regression. A geostatistical analysis was also carried out to determine the comfort zoning of broilers as a function of the THI intervals. In this way, the THI spatial mapping methodologies and trend analysis for the prediction of a possible future climate scenario can help in the development of risk maps for monitoring thermal comfort of broilers, being indispensable in the planning of actions for the mitigation of the climatic change impacts on the productive chain of the State of Minas Gerais.
\end{abstract}

Keywords: weather change, thermal environment, poultry farming, temperature and humidity index

\section{RESUMO}

O objetivo do presente trabalho foi estabelecer o zoneamento bioclimático por meio do índice de temperatura e umidade (ITU), considerando-se um período histórico e um cenário futuro, de forma a representar o ambiente térmico para criação de frangos de corte no estado de Minas Gerais. Foi utilizada uma série histórica (1976 - 2014) de ITU mínimo, médio e máximo, que foram calculados com base em dados oriundos de 48 estações meteorológicas convencionais, pertencentes ao Instituto Nacional de Meteorologia do Estado de Minas Gerais. A análise da série temporal se baseou no teste de Mann-Kendall e na regressão linear. Procedeu-se, também, à análise geoestatística para determinação do zoneamento do conforto de frangos de corte segundo os intervalos de ITU. Dessa forma, as metodologias de mapeamento espacial do ITU e a análise de tendência para predição de um possível cenário climático futuro podem auxiliar no desenvolvimento de mapas de risco para o monitoramento do conforto térmico de frangos de corte, sendo indispensáveis no planejamento de ações para mitigação dos impactos das mudanças climáticas sobre a cadeia produtiva do estado de Minas Gerais.

Palavras-chave: mudanças climáticas, ambiente térmico, avicultura, índice de temperatura e umidade

\section{INTRODUCTION}

The poultry production chain has been boosting a steady increase in this activity in several Brazilian states, especially Minas Gerais, which occupies the fifth position with a $9.4 \%$ share from the effective of the country (Produçao..., 2015). However, the State presents a great territorial extension, with relevant climatic complexity and important influence of the relief to the conformation of its microclimates (Ávila et al., 2014). These factors associated with the effects of climate change can cause

Recebido em 21 de maio de 2018

Aceito em 10 de dezembro de 2018

E-mail: pabloleal4@hotmail.com environmental temperature oscillations, significantly impacting poultry production in the region.

Much has been discussed since the 1980s on the impacts of climate change on animal production systems (Araújo, 2015). These changes in the Earth's climate are considered to be major causes of problems to animal welfare and productivity. On the other hand, although the influence of the thermal environment on the favoring or impairment of animal production performance is a subject widely discussed in Brazil, the studies 
on the effects of thermal conditions on these animals and their impacts on the productive sector are still scarce (Santos et al., 2014).

The high values of dry-bulb temperature $\left(\mathrm{t}_{\mathrm{db}}\right)$, commonly observed in tropical and subtropical countries, are considered the main interference factors in the production of broilers (Tinôco, 1996; Oliveira et al., 2006; Carvalho et al., 2009). Therefore, the productive environment maintenance within an appropriate temperature range for the animal species can be decisive for them to be able to express their productive potential.

In order to establish criteria for the classification of the thermal environment, several bioclimatic indices have been developed, of which the temperature and humidity index THI (Thom, 1959) stands out by the use of easily available meteorological information in databases of meteorological stations or satellite images (Oliveira et al., 2006). In addition, with the expansion of the information supply obtained by the geographic information system (GIS), the bioclimatic zoning of certain regions and the generation of alert maps associated with the weather forecast are increasingly accessible (Oliveira et al., 2006; Turco et al., 2006; Carvalho et al., 2009; Silva et al., 2009; Silva et al., 2010; Furtado and Crispim, 2015).

In view of the above, with the objective of the present research was to establish the bioclimatic zoning through the THI, considering a historical period and a future scenario, in order to represent the thermal environment for broilers in the State of Minas Gerais.

\section{MATERIAL AND METHODS}

The historical series (1976 - 2014) of the minimum, average and maximum THI (THImin, THIaverage and THImax, respectively) were obtained by determining the THI from tdb data and relative humidity $(\mathrm{RH})$ of the air for this period. These data come from 48 conventional meteorological stations, belonging to the National Institute of Meteorology (INMET), located in the State of Minas Gerais (Figure 1).

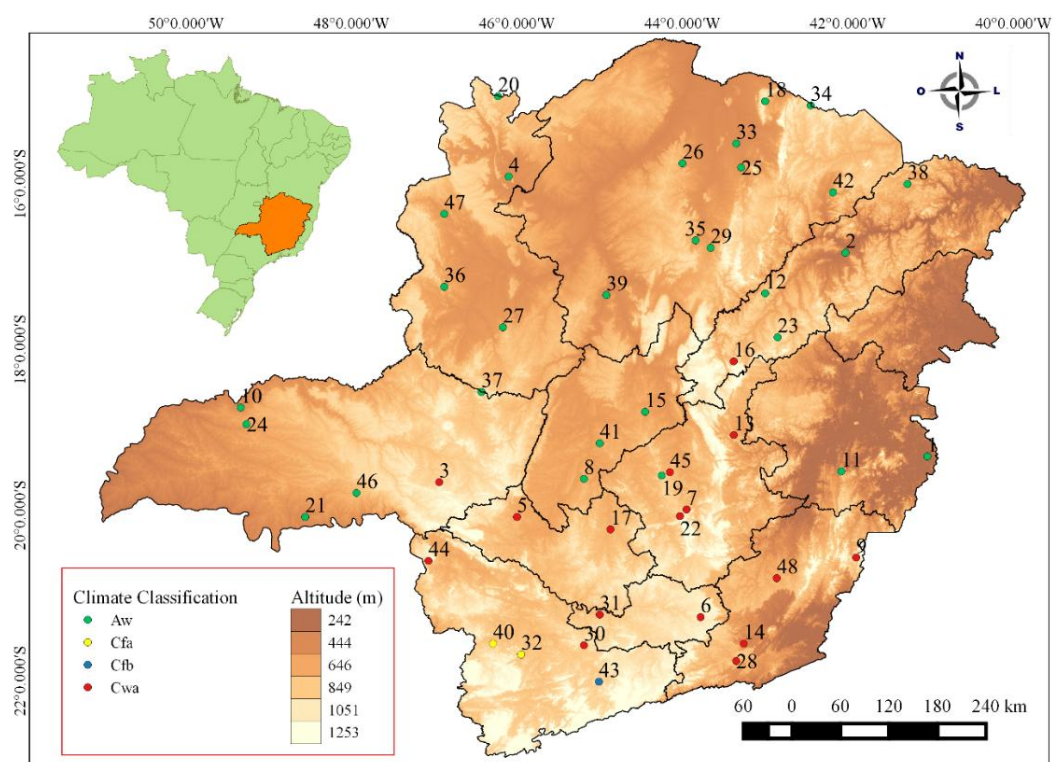

Figure 1. Geographic location, climatic classification and altitude of meteorological stations.

The THI, proposed by Thom (1959), was determined through equation 1 from the values of $\mathrm{tdb}$ min, tdb average, $\operatorname{tdb} \max \left({ }^{\circ} \mathrm{C}\right)$ and the dew-point temperature $\left(\operatorname{tdp},{ }^{\circ} \mathrm{C}\right)$. The tdp was

$$
\begin{aligned}
& \text { THI }=t_{d b}+0.36 \cdot t_{d p}+41.5 \\
& t_{d p}=(186.4905-237.3 \log e) /(\log e-8.2859)
\end{aligned}
$$

calculated through equation 2 (Vianello and Alves, 2012), where e is the actual water vapor pressure $(\mathrm{hPa})$. 
The nonparametric test of Mann-Kendall (Mann, 1945; Kendall, 1975), proposed by Sneyers (1975) and the linear regression analysis were applied to the historical series of THImin, THIaverage, THImax for the trends study. These analyzes have been applied in several studies (Luiz et al., 2012; Penereiro et al., 2012; Lopes and Silva, 2013; Ávila et al., 2014; Cera and Ferraz, 2015; Tian et al., 2016).

$$
\begin{aligned}
& S=\sum_{i=1}^{n-1} \sum_{j=i+1}^{n} \operatorname{sgn}\left(X_{j}-X_{i}\right) \\
& \operatorname{sgn}\left(X_{j}-X_{i}\right)=\left\{\begin{array}{rr}
1, & \text { if }\left(X_{j}-X_{i}\right)>0 \\
0, & \left(X_{j}-X_{i}\right)=0 \\
-1, & \left(X_{j}-X_{i}\right)<0
\end{array}\right.
\end{aligned}
$$

In the Mann-Kendall test, whether the stability of the time series exist (null hypothesis), the sequence of values occurs independently, and the probability distribution remains unchanged characterizing a simple random series. The $\mathrm{S}$ statistic was performed through equation 3 , where $\mathrm{n}$ is the number of observations, $\mathrm{xj}$ and $\mathrm{xi}$ are the sequential data points in the time series and $\operatorname{sgn}(\phi)$ is the signal function (equation 4$)$.

The positive value of $\mathrm{S}$ indicates an increasing trend, while a negative value indicates decreasing. For $\mathrm{n}$ greater than 10 and time series approximately normal distribution, the variance of the slope value can be calculated by equation 5. The $\mathrm{m}$ is the groups' association classification number, each associated with a ti.

$$
\operatorname{Var}(\mathrm{S})=\frac{\mathrm{n} \cdot(\mathrm{n}-1) \cdot(2 \cdot \mathrm{n}+5)-\sum_{\mathrm{i}=1}^{\mathrm{m}} \mathrm{ti} \cdot(\mathrm{ti}-1) \cdot(2 \cdot \mathrm{ti}+5)}{18}
$$

The standard normal test statistics $\mathrm{Z}$ can be used for detecting a significant trend (equation 6).

$$
Z=\left\{\begin{array}{cc}
\frac{s-1}{\sqrt{\operatorname{Var}(s)},} & \text { if } S>0 \\
0, & \text { if } S=0 \\
\frac{s+1}{\sqrt{\operatorname{Var}(s)},} & \text { if } S<0
\end{array}\right.
$$

A positive value of $\mathrm{Z}$ indicates an increasing trend, while a negative value indicates a decreasing trend. Considering the threshold of $5 \%$ significant level, in a two-tailed test Z0.975 = 1.96. Thus, the null hypothesis will be rejected if the Mann-Kendall test, $|\mathrm{MK}|>\mathrm{Z} 1-\mathrm{a} / 2$, is greater than 1.96 , indicating a significant trend in the data time series (Ávila et al., 2014).

Linear regression analysis was applied to obtain the trends by the parametric test of $t$ significance over the angular coefficient $(\beta)$ (Longobardi and Villani, 2010). This test considers the linear regression between the dependent (Y: THI series) and independent (X: Time) variables. The trend for a period of 10 years (2024) was calculated using the adjusted linear equations.
Interval maps of THImin, THIaverage and THImax for the State of Minas Gerais were generated in order to proceed with bioclimatic zoning. These maps looked at the historical period (1976 - 2014) and the future scenario (2024), that is, a decade after the end of the historical series of data.

The regression analysis and generation of maps were performed using the programs $R$ ( $R$ Development..., 2014) and ArcGIS for Desktop 10.4 , respectively. In order to analyze the spatial dependence of the THI in the State of Minas Gerais, semi variograms were adjusted by the ordinary minimum squares method (OLS), adjusting the spherical model, being the ordinary kriging the method used to interpolate the data (Ferraz et al., 2015). 
Regarding to the classification of THI intervals for broilers, the THI values below 74 characterize a condition of thermal comfort for these animals; between 74 and 79, represent alert situations; between 79 and 84 indicate danger and values above 84 configure emergency situations (Thom,1959; Hahn, 1982; Rosemberg et al., 1983; Du Preez et al., 1990; Hubbard et al., 1999; Cabral, 2001; Huhnke et al., 2001; Medeiros, 2001; Silva et al., 2004; Silva et al., 2005; Oliveira et al., 2006; Lavor et al., 2008; Carvalho et al., 2009; Osorio et al., 2016).

\section{RESULTS AND DISCUSSION}

By means of the spatial distribution of the historical average values of THImin and THIaverage (1976-2014), the predominance of ideal thermal comfort conditions (THI < 74) for the production of broilers for the four seasons of the year can be observed (Figure 2). However, in the spring period the elevation of the THIaverage for the range classified as alert $(74 \leq \mathrm{THI}<79)$ was observed in part of the mesoregion of the Triângulo Mineiro/Alto Paranaíba and part of the border of the Northwest and North mesoregions of Minas Gerais. These indications of elevation of the average THI in spring suggest the need to use artificial thermal conditioning systems, which allow the minimization of variations of the thermal environment inside the aviaries, reducing the problems related to thermal discomfort (Santos et al., 2014).

On the other hand, THImax values for the State of Minas Gerais (Figure 2), presented a predominance of a danger situation $(79 \leq \mathrm{THI}<$ 84 ) in most parts of the state in the spring, summer and autumn, and alert situation in winter, except for the mesoregions of South/Southwest of Minas, Campos das Vertentes, Zona da Mata, West of Minas and Belo Horizonte neighborhood, which, in winter, presented satisfactory comfort conditions for broilers (THI < 74). The prolonged stay of broilers under stressful thermal conditions, such as those observed in the present study, may interfere with the thermodynamic mechanisms of these animals, inhibiting feed consumption, increasing water consumption, which directly affect the weight gain and feed conversion of these birds, thus reducing their zootechnical indexes and raising mortality levels in the breeding stock (Silva et al., 2015).

Although there was an expansion of the areas classified as alert and danger to the thermal comfort of broilers in the THImax for the spring, summer and autumn, no situations of THI levels above 84 were observed for any of the four seasons of the historical period (1976 - 2014). The historical absence of this condition classified as extreme exposure to thermal stress for broilers, demanding for the producer emergency interventions to avoid losses in the establishment (Oliveira et al., 2006), does not guarantee to the producer a favorable environment for stimulating the growth of this productive chain throughout the entire State. According to the Intergovernmental Panel on Climate Change (IPCC) the climate scenarios projected for this century indicate that the planet's average temperature will continue to rise by at least $1.4^{\circ} \mathrm{C}$ and at most by about $5.8^{\circ} \mathrm{C}$, resulting in a further warming more pronounced than that of the 20th century (Marcott et al., 2013).

For Marengo et al. (2011), the combined effect of climate change on reducing rainfall, high temperatures, high evaporation rates and high competition for water resources can lead Brazil to a potentially catastrophic crisis, with farmers located in the most vulnerable areas of the State, such as the North of Minas and Jequitinhonha valley, the most prone to suffer their damaging effects.

The stress effects provided by the THImax usually occur at the peak times of temperature and daytime radiation, which, being below the values classified as emergency, can have their stress effects minimized. According to Abreu and Abreu (2011), the minimization of these stressful effects can be achieved through planning, architectural conception, and awareness from the poultry farmers regarding the best environmental management to be adopted for each mesoregion specifically. In this context, the higher productivity for broilers in these regions may be conditioned by the better adaptation of the facilities and the artificial thermal conditioning systems to the current environmental conditions and the needs of the birds. 

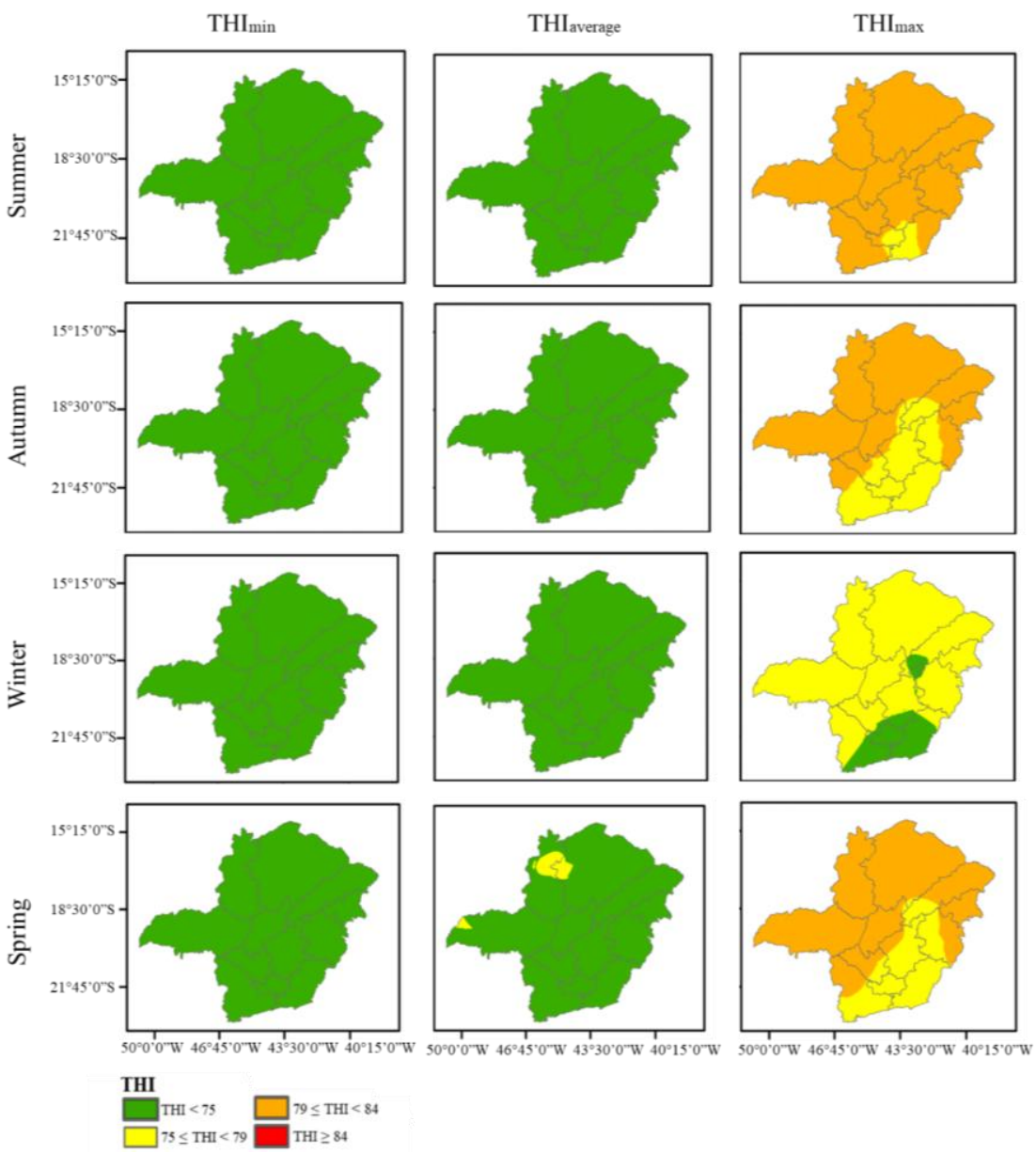

Figure 2. Variation of the minimum, medium and maximum temperature and humidity index (THI) for the summer, autumn, spring and winter from 1976 to 2014, in the municipalities evaluated in the State of Minas Gerais.

When comparing the historical averages (1976 2014) with the estimate for 2024 (Figure 3), it is verified that, although there has been a tendency to increase and reduce the values of THImin in different mesoregions of the State of Minas Gerais, the comfort condition thermal period for the THImin remained unchanged for the four seasons in year 2024 .

On the other hand, when we observe the behavior of the THIaverage for the year 2024, there is a tendency to reduce the thermal comfort condition for broilers, consequently the increase in the same proportions of the alert condition in $6.25 \% 0.00 \%, 0.00 \%$ and $2.08 \%$ for the summer, autumn, winter and spring seasons, respectively, when compared to historical means (1979-2014). There was also a trend towards an increase in the danger condition on THImax for the summer of
2024 in $6.25 \%$. The elevations of the stress conditions noted in this scenario, in its turn, can compromise the growth, body mass and meat quality of these animals, thus harming their productivity. According to McManus et al. (2012) under heat stress, these animals seek alternatives to lose excess heat produced by the body by diverting the energy from the diet to a series of adaptations of the respiratory, circulatory, excretory, endocrine and nervous systems, thus reducing their productive rates.

The projections obtained for the fall of 2024 indicate the reduction of THImax occurrences for comfort conditions in $2.08 \%$, alert and dangerous values remained unchanged and there was an increase in the emergency classification for THImax at $2.08 \%$ when the scenario of 2024 is compared to the historical period (1979-2014). 

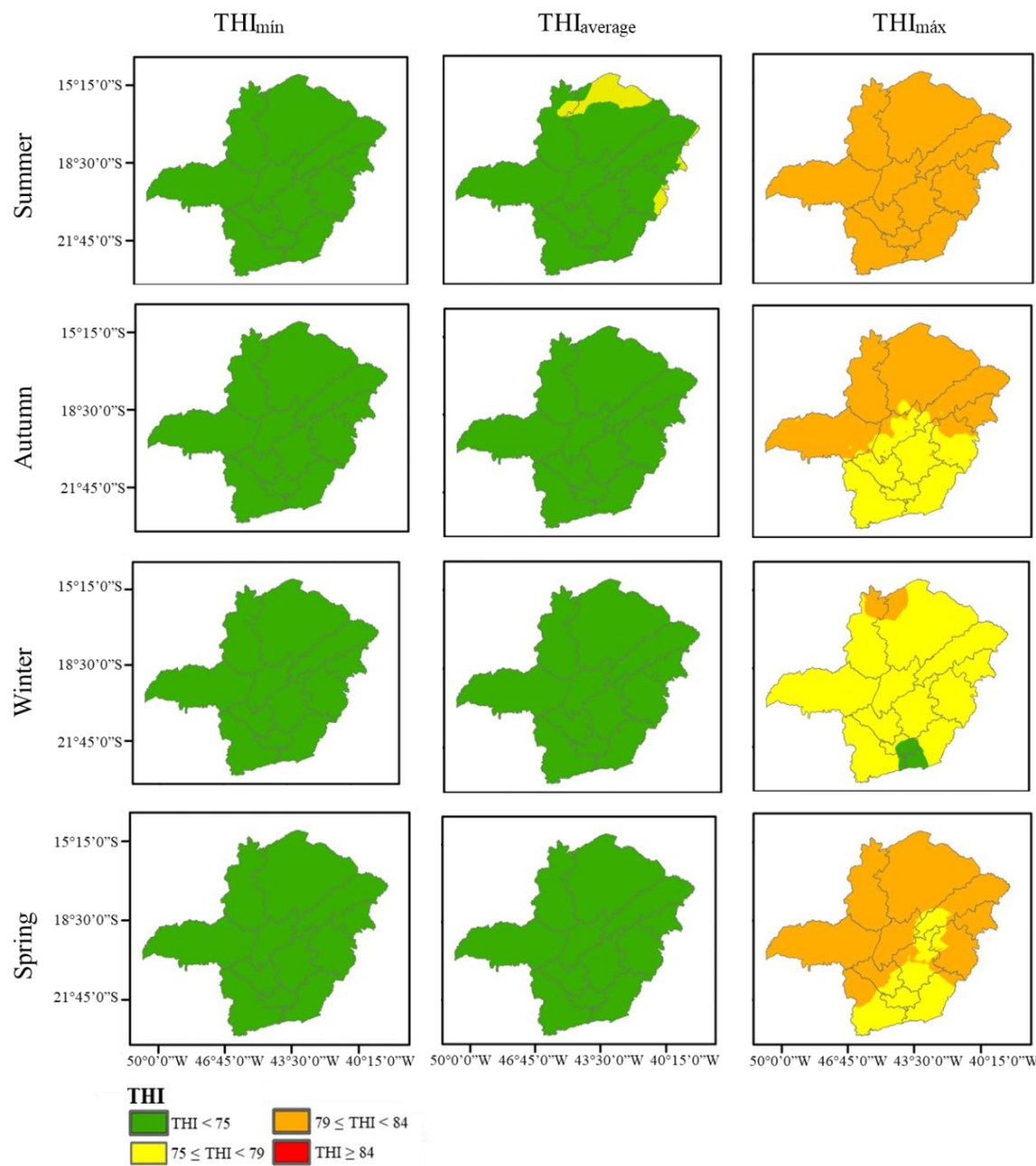

Figure 3. Trends of minimum, average and maximum temperature and humidity index (THI) for a decade, year 2024 in the different seasons of the year: summer, fall, spring and winter, in the municipalities evaluated in the State of Minas Gerais.

The trend analysis indicates, in general, the increase in the occurrence frequencies of the alert classification in the summer and spring seasons for THIaverage and THImax, when the 2024 scenario is compared to the historical period (1979-2014). These results corroborate with Marengo et al. (2011), who observed more intense changes in temperature projections in the months of January and February (summer), in the southern regions of Bahia and northern Minas Gerais, between the years 2010 and 2040. The studies of Vincent et al. (2005) and Obregon and Marengo (2007) also indicated an increase in annual average and extreme air temperatures in Brazil, where, according to Marengo et al. (2011), the historical records of air temperature (1961-2000), for some points in the Northeast, indicate the increase of minimum, average and maximum temperature in the order of 0.6-0.7; $0.5-0.6$ and $0.4-0.6^{\circ} \mathrm{C}$, respectively, in 30 years.

In the present study, the increase of danger condition in the autumn and spring time was also observed. This behavior may be conditioned to climatic variations and, as a consequence, an increasing discomfort may be observed for broilers, especially in the spring, summer and autumn. The knowledge about this possible climatic scenario and its uncertainties can help in planning actions to minimize the impact of thermal stress on production animals, such as the selection of animals physiologically and morphologically resistant to higher environmental temperatures, the supply of food with higher nutritional quality and reduction of caloric increment and the design of aviaries 
considering the use potential of primary and secondary modifications.

\section{CONCLUSIONS}

The historical series (1979-2014) of THImin and THIaverage indicated a thermal comfort for the production of broilers during the four seasons of the year, in all mesoregions of Minas Gerais, however, there was an expansion of the area classified as alert and danger to comfort thermal analysis when the THImax is analyzed during the spring, summer and fall, in this same period. Considering the future scenario, in 2024, THImin data remained similar to the period between 1979 and 2014, with THIaverage elevation in the spring and summer, besides the elevation of the THImax danger condition, characterizing thermal discomfort for the production of broilers. Methodologies such as the spatial mapping of the THI and the trend analysis for prediction of a possible future climate scenario may help in the development of risk maps for monitoring the thermal comfort of broilers, being indispensable in the action planning to mitigate the impacts of the climatic changes on the productive chain of the State of Minas Gerais.

\section{REFERENCES}

ABREU, V.M.N.; ABREU, P.G. Os desafios da ambiência sobre os sistemas de aves no Brasil. Rev. Bras. Zootec., v.40, p.1-14, 2011.

ARAÚJO, G.G.L. Os impactos das mudanças climáticas sobre os recursos hídricos e a produção animal em regiões semiáridas. Rev. Bras. Geogr. Fís., v.8, p.598-609, 2015.

ÁVILA, L.F.; MELLO, C.R.; YANAGI, S.N.M.; SACRAMENTO NETO, O.B. Tendência de temperaturas mínimas e máximas do ar no Estado de Minas Gerais. Pesqui. Agropec. Bras., v.49, p.247256, 2014.

CABRAL, J.L. Mapeamento da região sudeste do Brasil usando o ITU, para o gado de leite. 2001. 68f. Dissertação (Mestrado em Meteorologia Agrícola) Universidade Federal de Viçosa, Viçosa, MG.

CARVALHO, V.F.; YANAGI JUNIOR, T.; FERREIRA, L. et al. Zoneamento do potencial de uso de sistemas de resfriamento evaporativo no sudeste brasileiro. Rev. Bras. Eng. Agríc. Ambient., v.13, p.358-366, 2009.

CERA, J.C.; FERRAZ, S.E.T. Variações climáticas na precipitação no sul do Brasil no clima presente e futuro. Rev. Bras. Meteor., v.30, p.81-88, 2015.
DU PREEZ, J.D.; GIESECKE, W.H.; HATTINGH, P.J. Heat stress in dairy cattle and other livestock under Southern African conditions. I. Temperaturehumidity index mean values during the four main seasns. J. Vet. Res., v.57, p.77-87, 1990.

FERRAZ, G.A.S.; SILVA, F.M.; OLIVEIRA, M.S. et al. Variabilidade espacial da dose de $\mathrm{P}_{2} \mathrm{O}_{5}$ e $\mathrm{K}_{2} \mathrm{O}$ para adubação diferenciada e convencional em lavoura cafeeira. Coffee Sci., v.10, p.346-356, 2015.

FURTADO, G.D.; CRISPIM, M.C. Avaliação do comportamento em campo de um rebanho de caprinos das raças Saanen e Parda Alpina no Semiárido como contribuição para o entendimento do impacto do aquecimento global. Gaia Sci., v.9, p.28-36, 2015.

HAHN, G.L. Compensatory performance in livestock: influences on environmental criteria. In: INTERNATIONAL LIVESTOCK ENVIRONMENT SYMPOSIUM, 2. 1982, Ames. Proceedings... Ames: American Society of Agricultural Engineers, 1982. p.285-294.

HUBBARD, K.G.; STOOKSBURY, D.E.; HAHN, G.L.; MADER, T.L. A climatological perspective on feedlot cattle performance and morality related to the temperature-humidity index. J. Prod. Agric., v.12, p.650-653, 1999.

HUHNKE, R.L.; MCCOWAN, L.C.; MEREZ, G.M. et al. Determining the frequency and duration of elevated temperature-humidity index. In: ANNUAL MEETING, 2001, St. Joseph. Proceeding... St. Joseph: ASAE, 2001. 12p.

KENDALL, M.G. (Ed.). Rank correlation methods. London: Charles Griffin, 1975. 210p.

LAVOR, C.T.B.; FERNANDES, A.A.O.; SOUSA, F.M. Efeito de materiais isolantes térmicos em aviários no desempenho de frangos de corte. Rev. Ciênc. Agron., v.39, p.308-316, 2008.

LONGOBARDI, A.; VILLANI, P. Trend analysis of anual and seasonal rainfall time series in the Mediterranean area. Intern. J. Climat., v.30, p.15381546, 2010.

LOPES, J.R.F.; SILVA, D.F. Aplicação do teste de Mann-Kendall para análise de tendência pluviométrica no estado do Ceará. Rev. Geogr., v.30, p.192-208, 2013.

LUIZ, G.C.; CARDOSO, H.C.; RIBEIRO, L.L. Aplicação do teste sazonal de Mann Kendall na análise de tendência da temperatura e umidade relativa do ar - Gioânia - GO: Série histórica 1961 a 2008. Rev. Geonorte, v.1, p.414-427, 2012.

MANN, H.B. Nonparametric test against trend. Economectrika, v.13, p.245-259, 1945.

MARCOTT, A.S.; SHAKUN, J.D.; CLARK, P.U.; MIX, A.C. A reconstruction of regional and global temperature for the past 11.300 years. Science, v.339, p.1198-1201, 2013. 
MARENGO, J.A.; ALVES, L.M.; BEZERRA, E.A.; LACERDA, F.F. Variabilidade e mudanças climáticas no semiárido brasileiro. In: MEDEIROS, S.S.; GHEYI, H.R.; GALVÃO, C.O.; PAZ, V.P.S. (Eds.). Recursos hídricos em regiões áridas e semiáridas. Campina Grande: INSA, 2011. p.384-422.

McMANUS, C.; CANOZZI, M.E.; BRACELLOS, J.; PAIVA, S.R. Pecuária e mudanças climáticas. Rev. UFG. v.13, 2012.

MEDEIROS, C.M. Ajuste de modelos e determinação de índice térmico ambiental de produtividade para frangos de corte. 2001. 115f. Tese (Doutorado em Engenharia Agrícola). Universidade Federal de Viçosa. Viçosa, MG.

OBREGON, G.; MARENGO, J.A. Caracterização do clima do Século XX no Brasil: tendências de chuvas e temperaturas medias e extremas. Brasília: MMA/CPTEC/INPE, 2007. (Relatório n.2).

OLIVEIRA, L.M.; YANAGI JUNIOR, T.; FERREIRA, E. et al. Zoneamento bioclimático da região sudeste do Brasil para o conforto térmico animal e humano. Eng. Agríc., v.26, p.823-831, 2006.

OSORIO, H.R.; TINOCO, I.F.F.; OSORIO, S.J.A. et al. Thermal environment in two broiler barns during the first three weeks of age. Rev. Bras. Eng. Agríc. Ambient., v.20, p.256-262, 2016.

PENEREIRO, J.C.; FERREIRA, D.H.L.; GARCIA, V.F.V. Caracterização estatística de tendência climáticas em séries anuais de temperatura média e precipitação para as capitais estaduais do Brasil. Rev. Geintec, v.3, p.1-15, 2012.

PRODUÇÃO pecuária, produção da pecuária municipal. Rio de Janeiro, IBGE, 2015. Disponível em:

<http://downloads.ibge.gov.br/downloads_estatisticas. $\mathrm{htm}>$. Acessado em: 20 mar. 17.

R DEVELOPMENT CORE TEAM: A language and environment for statistical computing. Vienna: R Foundation for statistical computing, 2014. Available in: <http://www.R-project.org/>. Accessed in:22 Aug. 2017.

ROSENBERG, L.J.; BIAD, B.L.; VERNS, S.B. Human and animal biometeorology. In: Microclimate, the biological environment. New York: Wiley-Interscience Publication, 1983.

SANTOS, G.B.; SOUSA, I.F.; BRITO, C.O. et al. Estudo bioclimático das regiões litorânea, agreste e semiárida do estado de Sergipe para a avicultura de corte e postura. Ciênc. Rural, v.44, p.123-128, 2014.

SILVA, E.T.; LEITE, D.G.; YURI, F.M. et al. Determinação do índice de temperatura e umidade (ITU) para produção de aves na mesorregião metropolitana de Curitiba - PR. Revista Acad. Ciênc. Agric. Ambient., v.2, p.47-60, 2004.
SILVA, M.P.; BAÊTA, F.C.; TINÔCO, I.F.F. et al. Evaluation of the evaporative cooling usage potential for the Southeast region of Brazil with a simplified model for the estimation of the energy balance in sheds for broilers. In: LIVESTOCK ENVIRONMENT, 7., 2005, Beijing. Proceedings... Beijing: American Society of Agricultural and Biological Engineers, 2005. p.143-150.

SILVA, R.C.; RODRIGUES, L.R.; RODRIGUES, V.P. et al. Análises do efeito do estresse térmico sobre produção, fisiologia e dieta de aves. Agropecu. Cient. Semiárido, v.11, p.22-26, 2015.

SILVA, T.G.F.; MOURA, M.S.B.; SÁ, I.I.S. et al. Cenários de mudanças climáticas B1 e A1F1 e seus impactos na produção leiteira em estados nordestinos. Rev. Bras. Eng. Agríc. Ambient., v.14, p.863-870, 2010.

SILVA, T.G.F.; MOURA, M.S.B.; SÁ, I.I.S. et al. Impactos das mudanças climáticas na produção leiteira do estado de Pernambuco: análise para os cenários B2 e A2 do IPCC. Rev. Bras. Meteor., v.24, p.489-501, 2009.

SNEYERS, R. Sur L' analyse statistique des séries d' odbervations. Genève: Organization Météorologique Mondial, 1975. 192p. (OMM Note Technique, 143).

THOM, E.C. The discomfort index. Weatherwise, v.12, p.57-60, 1959.

TIAN, P.; MU, X.; LIU, J. et al. Impacts of climate variability and human activities on the changes of runoff and sediment load in a catchment of the Loess Plateau, China. Adv. Meteor., v.2016, 2016. Disponível em: <http://dx.doi.org/10.1155/2016/4724067>. Acessado em: 12 mar. 17.

TINÔCO, I.F.F. Efeito de diferentes sistemas de acondicionamento de ambiente e níveis de energia metabolizável na dieta, sobre o desempenho de matrizes de frangos de corte, em condições de verão e outono. 1996. 169f. Tese (Doutorado em Ciência Animal) - Escola de Veterinária, Universidade Federal de Minas Gerais, Belo Horizonte, MG.

TURCO, S.H.N.; SILVA, T.G.F.; SANTOS, L.F.C. et al. Zoneamento bioclimático para vacas leiteiras no estado da Bahia. Eng. Agric., v.26, p.20-27, 2006.

VIANELLO, R.L.; ALVES, A.R. (Eds.). Meteorologia básica e aplicações. Viçosa: UFV, 2012. 460p.

VINCENT, L.A.; PETERSON, T.C.; BARROS, V.R. et al. Odberved trends in indices of daily temperature extremes in South America 1960-2000. J. Climate, v.18, p.5011-5023, 2005. 